\title{
FAKTOR KUALITAS KEHIDUPAN KERJA DAN KETERLIBATAN KARYAWAN ${ }^{1)}$
}

\author{
Rusdin \\ Universitas Padjadjaran \\ e-mail: $\underline{\text { rusdin@unpad.ac.id }}$
}

\begin{abstract}
Efforts to realize the performance of SOEs is a very urgent requirement. This is related to the state ministry in Indonesia stakeholder's strategic plan 2012-2014. One important element in achieving this is improving the Quality Planning, Human Resources and Financial Management that can act as a surveillance tool as well as performance drivers. Therefore, through this study has explored: (1) the quality of work life, such as career plane, (2) organizational citizenship behavior, such as work ethic issues, and (3) employee engagement, such as remuneration policy issues. The research was conducted by applying a survey of 429 people Associate Manager at 141 state-owned enterprises in Indonesia. Data was collected by indirect communication techniques through instruments such as questionnaires and interview techniques through limited direct communication and documentation study. The study was conducted from January 2011, which ended December 31, 2012. The data processing techniques with descriptive analysis, the weighted mean score and inferential analysis of the Structural Equation Modeling (SEM). The results showed that: (1) Quality of work life, organizational citizenship behavior, employee engagement in SOEs in Indonesia showed a good condition, but not optimal, (2) quality of working life and organizational citizenship behaviors have a positive and significant effect on state employee engagement in Indonesia. The implications of this research, requiring hard work of the managers at levels 1 and 2 under the above directors and executive managers, to accommodate the interests of the manager as agent, and as the principal stakeholder's interests. Requires wisdom and policy decisions to implement the system of participation button up and participation from the top down.
\end{abstract}

Keywords: quality of work life, employee engagement

\footnotetext{
${ }^{1)}$ Survey ofMiddleManagersinState-Owned Enterprises(SOEs) inIndonesia
} 


\begin{abstract}
Abstrak
Upaya untuk mewujudkan kinerja BUMN merupakan tuntutan yang sangat mendesak. Hal tersebut terkait dengan upaya kementerian BUMN di Indonesia bersama stakeholder sebagai pemangku kepentingan dengan rencana strategis 2012-2014. Salah satu unsur penting dalam mewujudkan hal tersebut adalah peningkatan kualitas perencanaan, SDM, dan pengelolaan keuangan yang dapat berperan sebagai alat pengawasan sekaligus performance driver. Karenanya, melalui penelitian ini telah ditelaah kualitas kehidupan kerja meliputi keterlibatan sosial, partisipasi, kompensasi, integrasi target kerja, supervisi, lingkungan fisik, pertumbuhan dan pengembangan; dan keterikatan karyawan, meliputi keterikatan kognisi, keterikatan emosi, dan keteriktan perilaku. Penelitian ini dilakukan dengan menerapkan metode survei terhadap 429 orang Manajer Menengah pada 141 perusahaan BUMNdi Indonesia. Teknik pengumpulan data dilakukan dengan teknik komunikasi tidak langsung melalui instrumen berupa angket dan teknik komunikasi langsung melalui wawancara terbatas dan studi dokumentasi. Penelitian ini dilakukan dari bulan Januari 2011 - 31 Desember 2012. Teknik pengolahan data dilakukan dengan analisis deskriptif, yaitu rata-rata terbobot, dan analisis inferensial yaitu Structural Equation Modeling (SEM). Hasil penelitian menunjukkan bahwa: kualitas kehidupan kerja, meliputi keterlibatan sosial, partisipasi, kompensasi, integrasi target kerja, supervisi, lingkungan fisik, pertumbuhan dan pengembangan secara simultan dan parsial berpengaruh positif dan bermakna terhadap keterikatan karyawan pada BUMN di Indonesia. Implikasi dari penelitian ini, memerlukan kerja keras para manajer pada level 1 dan 2 di bawah direktur dan di atas manajer pelaksana, dengan mamadukan kepentingan manajer selaku agent, dan kepentingan stakeholder selaku principal. Memerlukan kearifan dan kebijakan dalam pengambilan keputusan dengan menerapkan sistem partisipasi dari bawah ke atas (bottom up) dan partisipasi dari atas ke bawah (top down).
\end{abstract}

Kata kunci: keterlibatan social,partisipasi, kompensasi, integrasi target kerja,supervisi,ligkungan fisik, pertumbuhan dan pengembangan, kualitas kehidupan kerja, keterikatan karyawan

\section{PENDAHULUAN}

Perusahaan makin tanggap terhadap kebutuhan karyawan, karena tidak ingin kehilangan orang-orang terbaiknya. Kendati demikian, isu bajak membajak karyawan masih sering terdengar. Gejalanya adalah perusahaan yang ingin melesat umumnya memilih membeli orangorang terbaik dari luar organisasi, kendati harus mengeluarkan biaya yang mahal. Idealnya hal ini berisiko menimbulkan suasana yang kurang kondusif bagi perkembangan karier karyawan yang sudah mengabdi selama puluhan tahun di perusahaan tersebut.

Kehadiran generasi baru di lingkungan kerja yang sama sekali berbeda dengan orang-orang 
sebelumnya atau biasa disebut Gen Y. Paradigma praktisi Human Capital (HC) pun harus berubah. Praktisi HC harus siap menerima generasi baru yang memiliki perilaku dan gaya bekerja yang berbeda dengan generasi sebelumnya. Gejala yang ada pada umumnya praktisi HC belum mampu bahkan tidak dapat merespons situasi ini dengan baik, yang muncul adalah suasana yang tidak kondusif. Idealnya karyawan dari generasi sebelumnya diarahkan untuk menjadi mentor bagi karyawan dari Generasi Y.

Masalah tarik ulur perundangundangan Ketenagakerjaan di Indonesia, gejalanya, yang menjadi pokok permasalahan antara lain: proses PHK dirasakan terlalu panjang dan jumlah pesangon yang dinilai memberatkan pengusaha; sering timbul masalah yang berkaitan dengan tenaga outsource dan perjanjian kerja waktu tertentu (PKWT) atau kontrak kerja; adanya perbedaan persepsi yang menimbulkan masalah sehubungan dengan cuti haid, kerja lembur, pengupahan, upah minimum provinsi/kabupaten/kota, dan penyusunan perjanjian kerja bersama (PKB); serta tumpang tindihnya beberapa undang-undang termasuk UU No 3/1992 tentang Jaminan Sosial Tenaga Kerja, UU No 13/2003 tentang Ketenagakerjaan, dan UU No 39/2004 tentang Perlindungan Tenaga Kerja Indonesia di luar negeri.

Kondisi tersebut tidak kondusif, Implementasi Undang-undang No 13/2003 masih dipertanyakan, bahkan saat ini masih direvisi dan sudah masuk proleknas, tapi tidak dibahas-bahas. Jadi efek sampingnya sangat besar. Investor tidak bisa masuk, sedangkan pengusaha lebih memilih tenaga outsource daripada merekrut karyawan permanen.

Energi kepercayaan dalam organisasi akan mengakumulasikan semua kekuatan positif, dan menciptakan kesiapan lingkungan organisasi untuk berinteraksi secara profesional dengan setiap fungsi dan peran kerja.

Sejalan dengan kondisi SDM pada perusahaan di Indonesia, maka tantangan SDM pada BUMN. 
Tabel 1.Tantangan Sumber Daya Manusia di BUMN

\begin{tabular}{|c|c|}
\hline Topik Masalah & Hasil Studi \\
\hline $\begin{array}{l}\text { 1.Membina } \\
\text { hubungan dengan } \\
\text { para manajer }\end{array}$ & $\begin{array}{l}\text { Manajer SDM mengalami kesulitan karena berbagai kepentingan (seperti } \\
\text { kepentingan antara agent dan principal) }\end{array}$ \\
\hline $\begin{array}{l}\text { 2.Manajemen } \\
\text { Talenta }\end{array}$ & $\begin{array}{l}\text { Manajer SDM mengalami kesulitan karena tingginya tuntutan dari } \\
\text { karyawan yang memiliki talenta }\end{array}$ \\
\hline $\begin{array}{l}\text { 3.Perekrutan } \\
\text { Karyawan } \\
\text { (Recruitment) }\end{array}$ & $\begin{array}{l}\text { Manajer SDM (sebagai Agent) mengalami kesulitan karena kebijakan } \\
\text { datangnya dari stakeholder (sebagai Principal) sehingga apa yang } \\
\text { diusulkan tidak sesuai dari hasil analisis jabatan yang dilakukan agent }\end{array}$ \\
\hline $\begin{array}{l}\text { 4.Manajemen biaya } \\
\text { SDM }\end{array}$ & $\begin{array}{l}\text { Manajer SDM kesulitan dalam mengelola biaya SDM karena berbagai } \\
\text { alasan seperti perencanaan SDM, hasil analisis jabatan, perekrutan, } \\
\text { diklat, pengelolaan prestasi, pengembangan karir, dan kompensasi, } \\
\text { memiliki gap yang tinggi antara apa yang dianggarkan dengan } \\
\text { realisasinya. }\end{array}$ \\
\hline $\begin{array}{l}\text { 5. Kinerja yang } \\
\text { belum optimal }\end{array}$ & $\begin{array}{l}\text { Karyawan tidak menunjukkan kinerja yang diharapkan, karena: (1) } \\
\text { karyawan tidak tahu apa yang diharapkan; (2) karyawan tidak memiliki } \\
\text { alat bantu, ruang atau otoritas; dan (3) karyawan tidak mendapat umpan } \\
\text { balik dari kualitas kerja mereka. }\end{array}$ \\
\hline $\begin{array}{l}\text { 6.Penanganan } \\
\text { permasalahan } \\
\text { karyawan }\end{array}$ & $\begin{array}{l}\text { Tidak selalu diselesaikan dengan tuntas, karena berbagai alasan (seperti: } \\
\text { birokrasi, biaya, dan pemahaman peraturan/perundang-undangan yang } \\
\text { multitafsir). }\end{array}$ \\
\hline
\end{tabular}

Sumber: Forum Human Capital Indonesia (HCI) BUMN, 2007disarikan oleh penulis, 2011

Terkait dengan harapan untuk meningkatkan upaya tersebut, diduga faktor pengelolaan SDM menjadi salah satu pendekatan yang perlu ditelaah lebih jauh. Setelah mengidentifikasi gejala yang mengarah ke suatu masalah, terkait dengan: (1) kualitas kehidupan kerja, meliputi keterlibatan sosial, partisipasi, kompensasi, integrasi target kerja, supervisi, ligkungan fisik, pertumbuhan dan pengembangan, dan (2) keterikatan karyawan, meliputi keterikatan kognisi, keterikatan emosional dan keterikatan perilaku, maka dapat dipahami bahwa karaketristik dari ke 2 (dua) variabel tersebut dapat ditemukan pada perusahaan BUMN di Indonesia. 
Tabel 2.Kecenderungan Karyawan BUMNDi Indonesia

\begin{tabular}{|c|c|}
\hline $\begin{array}{c}\text { Topik } \\
\text { Masalah }\end{array}$ & Hasil Studi \\
\hline $\begin{array}{l}\text { Keterikatan } \\
\text { sosial }\end{array}$ & $\begin{array}{l}\text { Terdapat kecenderungan terhadap perilaku sosial karyawan yang } \\
\text { meninggalkan BUMN untuk memilih bekerja pada perusahaan lain, baik di } \\
\text { dalam negeri mapun ke luar negeri, karena tidak kuatnya komitmen perusahaan } \\
\text { dalam mengikat pekerjanya (seperti konflik antar rekan sejawat, tidak } \\
\text { terjalinnya komunikasi vertikal yang baik atasan dengan bawahan, dan } \\
\text { permasalahan sosial lainnya) }\end{array}$ \\
\hline Partisipasi & $\begin{array}{l}\text { Terdapat kecenderungan karyawan pada tingkat lower manager jarang } \\
\text { dilibatkan dalam pengambilan keputusan (Top-Down) }\end{array}$ \\
\hline Kompensasi & $\begin{array}{l}\text { Terdapat kecenderungan karyawan merasa tidak mendapatkan kompensasi } \\
\text { finansial langsung yang adil dan mencukupi, sehingga karyawan } \\
\text { memanfaatkan kompensasi yang tidak langsung, seperti keselamatan dan } \\
\text { keamanan kerja, menunda-nunda pekerjaan dengan harapan diberikan waktu } \\
\text { untuk lembur, yang pada gilirannya akan menambah penghasilan. }\end{array}$ \\
\hline $\begin{array}{l}\text { Integrasi } \\
\text { tempat kerja, }\end{array}$ & $\begin{array}{l}\text { Terdapat kecenderungan karyawan belum terintegrasi dengan tempat kerjanya. } \\
\text { Hal tersebut terlihat pada seringnya terjadi mutasi, rotasi, dan demosi baik pada } \\
\text { tingkat atas, menengah, maupun pada tingkat bawah manager. }\end{array}$ \\
\hline Supervisi, & $\begin{array}{l}\text { Terdapat kecenderungan karyawan merasa terawasi setiap aktivitasnya, tidak } \\
\text { diberikan otonomi dalam berkerja, sehingga karyawan merasa bekerja penuh } \\
\text { tekanan, kesulitan dalam mengembangkan kreativitasnya untuk menciptakan } \\
\text { nilai (Value Creation), dan yang pada gilirannya menurunkan kinerja } \\
\text { karyawan. }\end{array}$ \\
\hline $\begin{array}{l}\text { Lingkungan } \\
\text { fisik, }\end{array}$ & $\begin{array}{l}\text { Kurangnya fasilitas utama maupun fasilitas pendukung yang disediakan } \\
\text { perusahaan bagi karyawan, atmosfir kerja tidak tercipta dengan baik sebagai } \\
\text { akibat dari lingkungan fisik yang tidak kondusif }\end{array}$ \\
\hline $\begin{array}{l}\text { Pertumbuhan } \\
\text { dan } \\
\text { pengembangan }\end{array}$ & $\begin{array}{l}\text { Pertumbuhan karyawan yang selalu mengalami peningkatan, namun kurang } \\
\text { dilakukan pengembangan. Akibatnya karyawan tidak merasa tertantang, } \\
\text { bekerja semaunya sebagai akibat posisi tempatnya bekerja tidak sesuai } \\
\text { kualifikasi dan minat karyawan. }\end{array}$ \\
\hline
\end{tabular}

Sumber:Studi Awaloleh penulis (2010)

Merujuk pada kondisi yang telah keterikatan karyawan (KK), diuraikan, maka masih belum jelas khususnya dalam konteks BUMN di benar, keterkaitan antara kualitas Indonesia. Dengan demikian kehidupan kerja (KKK) dan penelitian tentang hal tersebut 
penting untuk dilakukan, guna mengetahui kejelasan pola hubungan KKK dan KK pada BUMN di Indonesia.

\section{TINJAUAN LITERATUR}

Sehubungan dengan pentingnya peran SDM bagi perusahaan, maka diperlukan pengelolaan dan pengorganisasian secara terarah agar dapat memberikan sumbangan positif bagi peningkatan kinerja perusahaan (Carton dan Hofer, 2006:317). Dalam perkembangannya, SDM merupakan modal (asset) bagi organisasi yang dalam perspektif manajemen modern, SDM merupakan investasi bagi organisasi yang disebut sebagai Human Capital (Son, 2010).

Survei yang dilakukan oleh Chartered Management Institute (CMI, 2007) di Inggris yang melibatkan $1200 \quad$ manajer, berkesimpulan: (1) 8 dari $10(80 \%)$ manajer mengaku menghadapi kesulitan untuk memprioritaskan pekerjaan mereka, (2) 2 dari 3 $(66,67 \%)$ manajer mengeluh, karena mereka "tak punya waktu untuk berpikir", (3) lebih dari 50\% manajer, kesulitan mencari waktu untuk membuat perencanaan strategis, (4) kurang dari 50\% manajer, yang punya cukup banyak waktu luang untuk memperhatikan, mengevaluasi dan membina staf-nya, dan (5) lebih dari 40\% manajer, mengaku sering terjebak dalam politik-politik internal kantor. Dengan kata lain, jangankan untuk mengelola orang lain (karyawan), memikirkan kepentingan diri mereka sendiri (manajer) saja ternyata susah. Temuan lainnya, hanya satu dari 10 manajer yang mengaku punya waktu untuk rileks di luar jam kerja yang padat. Lebih dari 50\% manajer, menyalahkan budaya organisasi tempat mereka bekerja, khususnya pada "meeting yang terlalu banyak" (CMI, 2007). Rekomendasi dari hasil penelitian tersebut, bahwa "dalam iklim dewasa ini, memprioritaskan beragam tanggung jawab dan tugas di tempat kerja adalah tantangan nyata bagi para manajer. Organisasi perlu memberikan dukungan dan lingkungan yang terbuka, sehingga individu bisa menggunakan waktu untuk mengembangkan ide-ide segar untuk masa depan bisnis," (CMI, 2007). 
Kualitas Kehidupan Kerja/KKK (Quality Work of Life/QWL)

Kualitas kehidupan kerja (KKK), diperkenalkan pertama kali di Amerika Serikat untuk merujuk pada permasalahan dari rendahnya kualitas kehidupan kerja di dalam lingkungan internal organisasi. Perhatian KKK berasal dari serangkaian studi yang dilaksanakan oleh Trist dan Stamya (Saraji dan Dargahi, 2006) pada Institut Tavistockdi London. Temuan dalam studi ini sebagai dasar untuk teori sistem sosio-teknis yang banyak mengusahakan perubahan organisasi pekerja. Selanjutnya berbagai pandangan dalam memaknai kualitas kehidupan kerja (Quality of Work Life) dari tahun 2006 sampai dengan sekarang, seperti: Saraji dan Dargahi (2006), Rose, et., al., (2006), Gibson, et al., (2006), Umstot (Idrus, 2006:1), Jewell dan Siegell (Idrus, 2006:2), Feruniak (2008), Robbins dan Judge (2012) Kualitas kehidupan kerja (KKK), merupakan persepsi pegawai mengenai aspek dalam dunia kerja, berupa kesejahteraan fisik dan psikologis yang memberikan rasa aman dan kepuasan kerja baginya. Aspek yang dimaksud berkaitan dengan keterikatan karyawan, partisipasi, keadilan dan kecukupan kompensasi, integrasi tempat kerja, lingkungan fisik, kesempatan untuk pertumbuhan dan pengembangan dalam kehidupan kerja yang dilihat oleh karyawan sebagai sesuatu yang sangat diinginkan dan yang akan menambah kualitas kehidupan kerjanya.

Kualitas kehidupan kerja diukur dari berbagai sudut pandang, seperti Walton (Rose, et al., 2006) kompensasi yang adil dan cukup; lingkungan kerja yang sehat dan aman; kesempatan langsung untuk menggunakan dan mengembangkan kapasitas manusia; kesempatan untuk pertumbuhan yang berkelanjutan dan keamanan; Integrasi sosial dalam organisasi kerja; konstituasionalisme dalam organisasi kerja; ruang kerja dan hidup secara keseluruhan; relevansi sosial kehidupan kerja. 


\section{Keterikatan Karyawan (KK)}

Keterikatan karyawan (employee engagement) pertama kali dibangun oleh kelompok peneliti Gallup (Endres dan Smoak, 2008). Employee engagement telah diklaim dapat memprediksikan peningkatan produktivitas pada karyawan, profitabilitas, mempertahankan karyawan, kepuasan konsumen serta keberhasilan untuk organisasi (Richman, 2006), sehingga topik ini menjadi isu yang hangat diperbincangkan dikalangan akademisi dan profesional. Memaknai keterikatan karyawan (employee engagement) adalah sejauh mana tenaga kerja berkomitmen, baik emosional maupun intelektual, yang sifatnya relatif untuk menyelesaikan pekerjaan sesuai dengan misi dan visi organisasi.

Menurut Gallup (Endres dan Smoak, 2008), Pengukuran dan sistem umpan balik kepada pemilik perusahaan (employer) dengan mengidentifikasikan elemen-elemen keterikatan karyawan yang berkaitan langsung "bottom line", yaitu: (1)
Retensi Karyawan, (2) Customer Loyalty, (3) Profitabilitas,

Produktifitas, dan (5) Safety. Terdapat 3 tipe keterikatan karyawan, yaitu: terikat (engaged), tidak terikat (not Engaged), aktif tidak terikat (actively disengaged).

Chartered Institute of Personnel and Development (CIPD) UK (2010) mengamati employee engagement dari 3 dimensi, yaitu: (1) Emotional Engaged, karyawan terikat secara emosional dengan pekerjaannya, yaitu: komitmen terhadap oragnisasinya, komitmen terhadap pemimpinnya, dan komitmen dengan lingkungan kerjanya; (2) Cognitive Engaged, Karyawan benar-benar fokus pada pekerjaannya karena mengetahui \& memahami organisasinya, mengetahui \& memahami pemimpinnya, dan memahami \& mengetahui lingkungan kerjanya; dan

Physically Engaged, Karyawan memiliki kemauan keras dan semangat untuk "memberikan lebih" kepada pemilik perusahaan (employer), yaitu: terkait dengan pekerjaan yang dihadapinya, memiliki komitmen untuk berhasil 
dalam pekerjaannya, dan kagum/mencintai pekerjaannya

\section{Keterkaitan antar variabel}

Kualitas kehidupan kerja berkaitan dengan komitmen terhadap pekerjaan dan organisasi, kebanggaan dalam pekerjaan dan dalam organisasi, kesediaan untuk mendukung manfaat dan keuntungan dari pekerjaan dan organisasi, dan kepuasan dengan pekerjaan dan organisasi, baik emosional maupun intelektual. Keempat hal tersebut terdapat pada employee engagement yang ditunjukkan oleh hasil penelitian Haid dan Sims (2012), yang mengidentifikasi employee engagement dengan menggunakan empat faktor definitif: (1) Komitmen terhadap pekerjaan dan organisasi; (2) Kebanggaan dalam pekerjaan dan dalam organisasi; (3) Kesediaan untuk mendukung manfaat dan keuntungan dari pekerjaan dan organisasi; dan (4) Kepuasan dengan pekerjaan dan organisasi.

Hasil penelitian Ross, et al., (2006) yang dilakukaanterhadap 475 eksekutif dari perusahaan listrik di kawasan perdagangan bebas Malaysia, yang mengungkapkan kepuasan karir, pencapaian karir dan keseimbangan karir berpengaruh secara signifikan terhadap $Q W L$. Ketiga faktor tersebut diperkuat oleh hasil penelitian Sardar, et al (2010) yang mengungkapkan hubungan yang signifikan antara employee engagement dan pembuatan keputusan dan aspek-aspek lainnya dalam praktik MSDM yang diteliti.

Hasil penelitian Schaufeli dan Bakker(2008) menunjukkan bahwa (1) keterikatan karyawan dengan memimpin perusahaan memberikan pengaruh terhadap kepuasan pelanggan yang akhirnya mengarahkan organisasi terhadap hasil profitabilitas atau bisnis, dan(2) terdapat hubungan yang kuat antara keterikatan karyawan dengan kinerja perusahaan dan produk akhir, meskipun ditemukan bahwa organisasi yang berbeda mendefinisikan keterikatan yang berbeda, tetapi ada beberapa kesamaan dalam paraktik.

Berdasarkan hasil penelitian Ross, et al (2006), Sardar, et al (2010), dan Haid dan Sims (2012), menunjukkan bahwa karateristik yang terdapat pada keterikatan 
karyawan digambarkan pula oleh karakteristik yang terdapat pada kualitas kehidupan kerja. Dalam hasil studi lain ditunjukkann bahwa perilaku kewargaan organisasi berpengaruh terhadap keterikatan karyawan, hal ini ditunjukkan oleh hasil penelitian Ehigie dan Otukoya (2005), berkesimpulan bahwa untuk meningkatkan perilaku kewargaan organisasional antara karyawan dengan organisasi, terutama perusahaan milik pemerintah di Nigeria, manajemen perlu menetapkan perangkat kebijakan di tempat kerja yang akan menjamin peningkatan dukungan organisasi dan perlakuan yang adil terhadap semua orang dari tiga aspek perilaku kewargaan organisasi, yaitu membantu, kebajikan sipil, dan sportivitas.

Hal tersebut sejalan dengan faktor penggerak keterikatan karyawan, yaitu: (1)Organisasi, hal terkait organisasi yang dapat menjadi penggerak keterikatan karyawan adalah budaya organisasi, visi dan nilai yang dianut, merek organisasi. Budaya organisasi yang dimaksud adalah budaya organisasi yang memiliki keterbukaan dan sikap supportive serta komunikasi yang baik antara rekan kerja, sehingga karyawan dapat memberikan ekstra peran yang tidak meminta imbalan di luar peran yang seharusnya dilakukan, yaitu apa yang dikenal dengan perilaku kewargaan organisasional. Keadilan dan kepercayaan sebagai nilai organisasi juga memberikan dampak positif bagi terciptanya keterikatan karyawan. Hal tersebut akan memberikan persepsi bagi karyawan bahwa mereka mendapat dukungan dari organisasi; (2) Manajemen dan Kepemimpinan, keterikatan dibangun melalui proses, butuh waktu yang panjang serta komitmen yang tinggi dari pemimpin. Untuk itu, dibutuhkan konsistensi pemimpin dalam memandu karyawan dalam menciptakan keterikatan karyawan, pemimpin organisasi diharapkan memiliki beberapa keterampilan, seperti teknik berkomunikasi, teknik memberikan feedback dan teknik penilaian kinerja (McBain, 2007); (3)Working life, kenyamanan kondisi lingkungan kerja menjadi pemicu terciptanya keterikatan karyawan.

Dengan demikian, upaya memberikan peluang karayawan 
untuk berpartisipasi tidak terlepas dari: peran organisasi, kepemimpinan, dan kondisi lingkungan pekerjaan. Dalam kaitan ini ketiga faktor tersebut menjadi pendorong terjadinya keterikatan karyawan.

Hasil penelitian Sark, et al., (2006) menunjukkan, 6 faktor yang mempengaruhi keterikatan karyawan dengan perusahaannya, yaitu:

komunikasi dalam perusahaan, (2) kondisi kerja, (3) evaluasi dan pengembangan SDM, (4) ketentuan perusahaan, (5) reward dan remunerasi serta layanan SDM dari perusahaan. Dikaitkan dengan konstruksi dan indikator keterikatan karyawan yang telah dijelaskan sebelumnya, survei di berbagai negara menunjukan perbedaan faktor yang mempengaruhi keterikatan karyawan.

Merujuk pada kajian konseptual dan hasil penelitian sebelumnya maka dugaan penulis dapat dirumuskan bahwa kualitas kehidupan kerja meliputi keterlibatan sosial, partisipasi, kompensasi, integrasi target kerja, supervisi, ligkungan fisik, pertumbuhan dan pengembangan secara simultan dan parisial berpengaruh terhadap keterikatan karyawan pada BUMN di Indonesia.

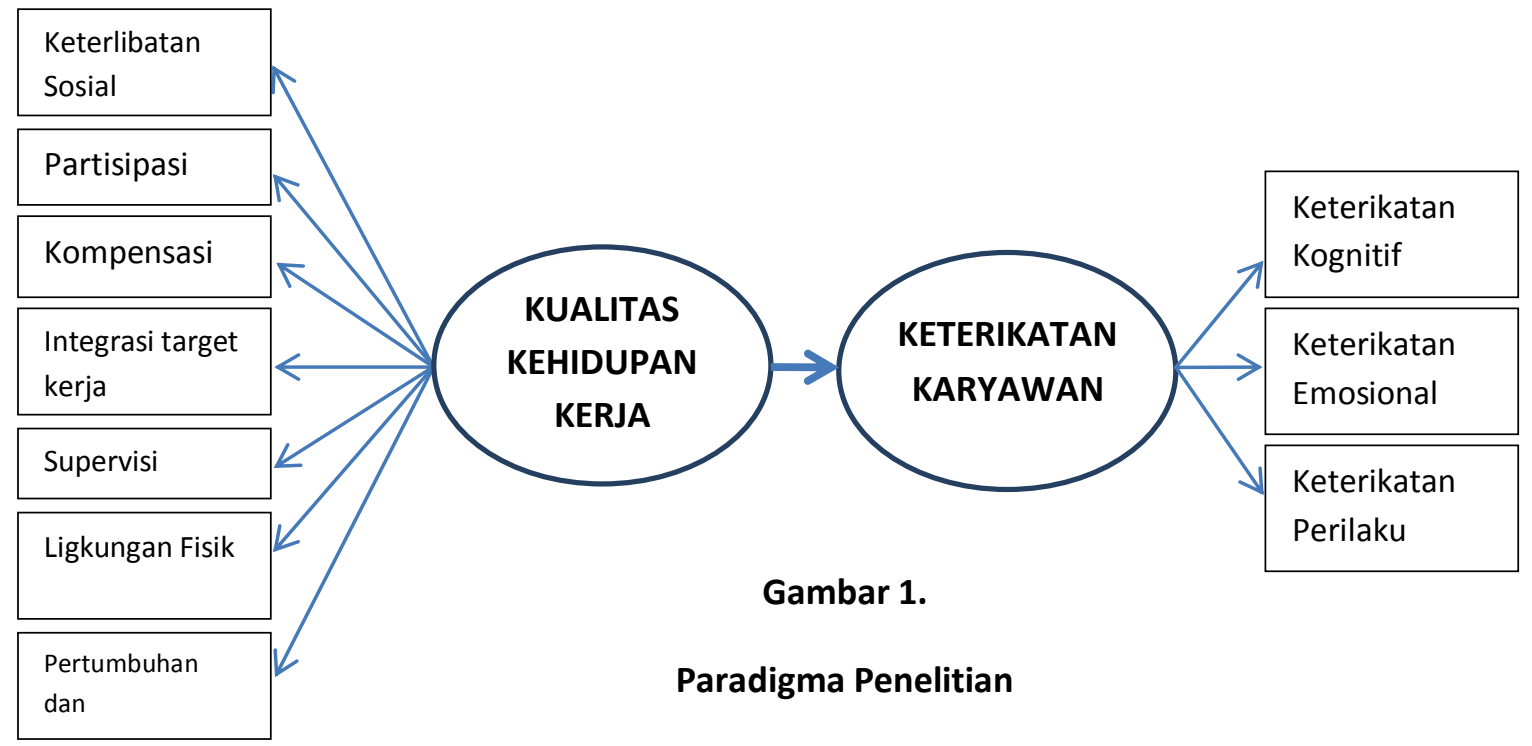


Hipotesis Penelitian

$\begin{array}{lrr}\text { Kualitas } & \text { kehidupan } & \text { kerja } \\ \text { meliputi: keterlibatan } & \text { sosial, } \\ \text { partisipasi, kompensasi, } & \text { integrasi } \\ \text { target kerja, supervisi, } & \text { ligkungan } \\ \text { fisik, pertumbuhan } & \text { dan } \\ \text { pengembangan secara simultan dan } \\ \text { parisial berpengaruh terhadap } \\ \text { keterikatan karyawan pada BUMN di } \\ \text { Indonesia. }\end{array}$

\section{METODE PENELITIAN}

Penelitian ini menggunakan Metode Survei Penjelasan (Explanatory Survei Method). Bertujuan untuk menguji hipotesis yang telah dirumuskan sebelumnya. Walaupun uraiannya juga mengandung deskripsi, tetapi sebagai penelitian relasional fokusnya terletak pada penjelasan hubungan antar variabel. Konsekuensi penelitian ini diperlukan operasionalisasi variabel yang lebih mendasar kepada konstruk dan indikatornya. Sesuai dengan hipotesis yang diajukan, dalam penelitian ini digunakan pengujian hipotesis inferensial/verifikasi dengan Structural Equation Modeling (SEM), dengan alasan bahwa model ini merupakan pendekatan terintegrasi antara
Confirmaatory Factor Analysis, Structural Model, dan Path Analysis. Hal ini sejalan dengan pandangan Jöreskog dan Sörbom (2006) dan Wijanto (2008) yang menyatakan bahwa dengan menggunakan SEM peneliti dapat memperoleh tiga manfaat sekaligus, yaitu: (1) pemeriksaan validitas dan reliabilitas instrumen (setara dengan faktor analisis konsfimatori/Comfirmatory Factor Analysis-CFA); (2) pengujian hubungan antara variabel laten (setara dengan Path Analysis); dan (3) mendapatkan model yang bermanfaat untuk prediksi (setara analisis regresi dengan Model Struktural/ Structural Models). Penelitian ini mengungkap mengenai tingkat keberlakuan umum atau generalisasi dari hasilnya, dibatasi pada fenomena yang terjadi dilokasi penelitian.

Variabel keterikatan karyawan/KKK (Quality Work of Life/QWL), diukur melalui indikatorindikator yang merupakan ciri dari variabel ini, yang dioperasionalkan menjadi 19 pernyataan, dengan menggunakan instrumen berupa kuesioner. 
Variabel

Keterikatan

Karyawan/KK

(Employee

Engagement), diukur melalui

indikator-indikator yang merupakan ciri dari variabel ini, yang dioperasionalkan menjadi 10 pernyataan, dengan menggunakan instrumen berupa kuesioner.
Hasil dari kuesioner ini merupakan data yang berskala ordinal, dengan skor berkisar 1- 5 setiap itemnya, seperti terlihat pada Tabel 3.

Tabel 3. Option, skoring dan interpretasi setiap pernyataan/pertanyaan

\begin{tabular}{|c|c|c|}
\hline Option & Skor & Interpretasi \\
\hline Selalu (SL) & $5(1)$ & Sangat Baik (Buruk) \\
\hline Sering (SR) & $4(2)$ & Baik (Kurang Baik) \\
\hline Kadang-kadang (KD) & $3(3)$ & Sedang (Cukup) \\
\hline Jarang (JR) & $2(4)$ & Kurang Baik (Baik) \\
\hline Tidak Pernah (TP) & $1(5)$ & Buruk (Sangat Baik) \\
\hline \multicolumn{3}{|c|}{ Sumber: diadopsi dari Likert (Wilson, 2005) } \\
\hline \multicolumn{2}{|c|}{$\begin{array}{l}\text { Unit populasi dalam penelitian } \\
\text { ini } 141 \text { BUMN, sedangkan unit } \\
\text { observasinva } 36.619 \text { orang manaier }\end{array}$} & $\begin{array}{l}\text { pembuat/pengambil keputusan di } \\
\text { level } 1 \text { dan/atau level } 2 \text { di bawah } \\
\text { level Direksi (Top Manager) dan di } \\
\text { atas level manajer pelaksana (lower }\end{array}$ \\
\hline \multicolumn{2}{|c|}{$\begin{array}{l}\text { BUMN. Dengan menggunakan } \\
\text { teknik penarikan sampel secara }\end{array}$} & $\begin{array}{l}\text { manager). Manajer menengah selain } \\
\text { bertindak sebagai karyawan untuk } \\
\text { memberikan persepsi tentang }\end{array}$ \\
\hline \multicolumn{2}{|c|}{ sampel 429 orang manajer Menengah } & Kualitas Kehidupan Kerja (Quality of \\
\hline \multirow{2}{*}{\multicolumn{2}{|c|}{$\begin{array}{l}\text { diseluruh BUMN di Indonesia. } \\
\text { Berdasarkan tujuan penelitian ini, } \\
\text { maka manajer menengah dinilai }\end{array}$}} & Work Life) juga bertindak sebagai \\
\hline & & $\begin{array}{lrr}\text { pemimpin } & \text { (manajer) } & \text { dalam } \\
\text { memberikan } & \text { persepsi } & \text { tentang }\end{array}$ \\
\hline mewakili seluruh & $\mathrm{di}$ & karyawan (employee \\
\hline Indonesia, karena mar & & engagement) \\
\hline (middle manager) & & \\
\hline
\end{tabular}


Teknik pengumpulan data dilakukan dengan teknik komunikasi tidak langsung dan teknik komunikasi langsung. Teknik komunikasi tidak langsung menggunakan kuesioner sebagai instrumen. Sedangkan teknik komunikasi langsung menggunakan wawancara terbatas dan studi dokumentasi sebagai instrumen.

Analisis data dilakukan dengan 2 cara, yaitu: Descriptive Analysis dan Structural Equation Modeling. $\mathrm{H}_{0}: \gamma_{\mathrm{i}}$ $=0 ; \mathrm{H}_{\mathrm{i}}: \gamma_{1} \neq 0$. Tolak $\mathrm{H}_{0}$ untuk taraf nyata $95 \%(\alpha=0,05)$, jika nilai $p$ value $\geq \alpha$, sedangkan simultan $\mathrm{H}_{0}$ : $\gamma_{1+} \gamma_{2}=0 ; \mathrm{H}_{\mathrm{i}}: \gamma_{1+} \gamma_{2} \neq 0$. Tolak $\mathrm{H}_{0}$ untuk taraf nyata $95 \%(\alpha=0,05)$, jika nilai $p$-value $\geq \alpha$.
ANALISIS DAN PEMBAHASAN

Berdasarkan data dari Kementerian BUMN per 31 Desember 2011, jumlah BUMN terkait kepemilikan Pemerintah secara langsung dan berada di bawah kementerian BUMN, terdapat 141 BUMN yang terdiri dari 14 BUMN berbentuk Perum, 109 BUMN berbentuk Persero, dan 18 BUMN yang merupakan Persero Terbuka. Selain itu, Negara juga mempunyai kepemilikan saham minoritas pada 15 badan usaha. Perkembangan jumlah BUMN dan kepemilikan Negara minoritas tahun 20052011 dapat diringkaskanke dalam Tabel 4. 
Tabel 4. Perkembangan Jumlah BUMN dan Kepemilikan Negara Minoritas pada Badan Usaha Tahun 2005-2011

\begin{tabular}{lccccccc}
\hline \multirow{2}{*}{ Uraian } & \multicolumn{7}{c}{ T A H U N } \\
\cline { 2 - 7 } & $\mathbf{2 0 0 5}$ & $\mathbf{2 0 0 6}$ & $\mathbf{2 0 0 7}$ & $\mathbf{2 0 0 8}$ & $\mathbf{2 0 0 9}$ & $\mathbf{2 0 1 0}$ & $\mathbf{2 0 1 1}$ \\
\hline Perum & 13 & 13 & 14 & 14 & 14 & 14 & 14 \\
Persero & 114 & 114 & 111 & 113 & 112 & 111 & 109 \\
Persero Tbk & 12 & 12 & 14 & 14 & 15 & 17 & 18 \\
\hline Mayoritas : & 139 & 139 & 139 & 141 & 141 & 142 & 141 \\
\hline Minoritas & 21 & 21 & 21 & 21 & 19 & 15 & 15 \\
\hline Total & $\mathbf{1 6 0}$ & $\mathbf{1 6 0}$ & $\mathbf{1 6 0}$ & $\mathbf{1 6 2}$ & $\mathbf{1 6 0}$ & $\mathbf{1 5 7}$ & $\mathbf{1 5 6}$ \\
\hline
\end{tabular}

Sumber: Hasil Studi Dokumentasi, diolah penulis 2012

Tabel 5. Jenis KelaminResponden Berdasarkan Klasifikasi Badan Usaha

\section{BUMN}

\begin{tabular}{lcccccc}
\hline \multirow{2}{*}{$\begin{array}{l}\text { BENTUK BADAN } \\
\text { USAHA BUMN }\end{array}$} & \multicolumn{2}{c}{ Laki } & \multicolumn{2}{c}{ Wanita } & \multirow{2}{*}{ Jumlah } & \% \\
\cline { 2 - 6 } & Jumlah & \% & Jumlah & \% & & \\
\hline PERUM & 23 & 71.88 & 9 & 28.13 & 32 & 7.46 \\
PERSEROAN & 305 & 85.43 & 52 & 14.57 & 357 & 83.22 \\
PERSEROAN TERBUKA & 23 & 57.50 & 17 & 42.50 & 40 & 9.32 \\
\hline Jumlah & 351 & 71.60 & 78 & 28.40 & 429 & 100
\end{tabular}

Sumber: Hasil Rekapitulasi dari Kuesioner, diolah penulis 2013 
Tabel 6. Tingkat PendidkanResponden Berdasarkan Klasifikasi Badan Usaha BUMN

\begin{tabular}{|c|c|c|c|c|c|c|c|c|}
\hline $\begin{array}{l}\text { TINGKAT } \\
\text { PENDIDIK } \\
\text { AN }\end{array}$ & $\begin{array}{c}\text { PERU } \\
\text { M }\end{array}$ & $\%$ & $\begin{array}{c}\text { PERSER } \\
\mathbf{O}\end{array}$ & $\%$ & $\begin{array}{c}\text { PERSER } \\
\text { O } \\
\text { TERBUK } \\
\text { A }\end{array}$ & $\%$ & $\begin{array}{c}\mathbf{J M} \\
\mathbf{L}\end{array}$ & $(\%)$ \\
\hline Strata $3(\mathrm{~S} 3)$ & 0 & 0.00 & 8 & 2.24 & 2 & 5.00 & 10 & 2.33 \\
\hline Strata $2(\mathrm{~S} 2)$ & 11 & $\begin{array}{r}34.3 \\
8\end{array}$ & 98 & $\begin{array}{r}27.4 \\
5\end{array}$ & 23 & $\begin{array}{r}57.5 \\
0\end{array}$ & 132 & $\begin{array}{r}30.7 \\
7\end{array}$ \\
\hline Strata 1 (S1) & 19 & $\begin{array}{r}59.3 \\
8\end{array}$ & 249 & $\begin{array}{r}69.7 \\
5\end{array}$ & 15 & $\begin{array}{r}37.5 \\
0\end{array}$ & 283 & $\begin{array}{r}65.9 \\
7\end{array}$ \\
\hline $\begin{array}{l}\text { Diploma } \\
\text { (S0) }\end{array}$ & 2 & 6.25 & 2 & 0.56 & 0 & 0.00 & 4 & 0.93 \\
\hline Jumlah & 32 & 100 & 357 & 100 & 40 & 100 & 429 & 100 \\
\hline $\begin{array}{l}\text { Persentase } \\
(\%)\end{array}$ & 7.46 & & 83.22 & & 9.32 & & 100 & \\
\hline
\end{tabular}

Sumber: Hasil Rekapitulasi dari Kuesioner, diolah penulis 2013

Tabel 7. Lama Berkerja pada BUMN Berdasarkan Klasifikasi Bentuk Badan Usaha BUMN

\begin{tabular}{lrrrrrr}
\hline $\begin{array}{l}\text { BENTUK BADAN } \\
\text { USAHA }\end{array}$ & $\mathbf{3 0}$ Th & $\mathbf{\%}$ & $<\mathbf{3 0}$ Th & $\mathbf{\%}$ & Jumlah & $\begin{array}{r}\text { Persentase } \\
\text { (\%) }\end{array}$ \\
\hline PERUM & 24 & 75.00 & 8 & 25.00 & $\mathbf{3 2}$ & $\mathbf{7 . 4 6}$ \\
PERSEROAN & 317 & 88.80 & 40 & 11.20 & $\mathbf{3 5 7}$ & $\mathbf{8 3 . 2 2}$ \\
PERSEROAN (Tbk) & 21 & 52.50 & 19 & 47.50 & $\mathbf{4 0}$ & $\mathbf{9 . 3 2}$ \\
\hline Jumlah & $\mathbf{3 6 2}$ & & $\mathbf{6 7}$ & & $\mathbf{4 2 9}$ & $\mathbf{1 0 0}$ \\
\multicolumn{1}{c}{$\%$} & $\mathbf{8 4 . 3 8}$ & & $\mathbf{1 5 . 6 2}$ & & $\mathbf{1 0 0}$ & \\
\end{tabular}

Sumber: Hasil Rekapitulasi dari Kuesioner, diolah penulis 2013 
Tabel 8. Lama Berkerja sebagai Manajer MenengahBerdasarkan Klasifikasi Bentuk Badan Usaha BUMN

\begin{tabular}{lcccccc}
\hline $\begin{array}{l}\text { BENTUK BADAN } \\
\text { USAHA }\end{array}$ & $<\mathbf{5}$ Th & $\mathbf{\%}$ & $\mathbf{2} \mathbf{5}$ Th & $\mathbf{\%}$ & Jumlah & $\begin{array}{c}\text { Persentase } \\
\mathbf{( \% )}\end{array}$ \\
\hline PERUM & 27 & 84.38 & 5 & 15.63 & 32 & $\mathbf{7 . 4 6}$ \\
PERSEROAN & 339 & 94.96 & 18 & 5.04 & 357 & $\mathbf{8 3 . 2 2}$ \\
PERSEROAN(Tbk) & 32 & 80.00 & 8 & 20.00 & 40 & $\mathbf{9 . 3 2}$ \\
\hline Jumlah & $\mathbf{3 9 8}$ & & $\mathbf{3 1}$ & & $\mathbf{4 2 9}$ & $\mathbf{1 0 0}$ \\
\hline$\%$ & $\mathbf{9 2 . 7 7}$ & & $\mathbf{7 . 2 3}$ & & $\mathbf{1 0 0}$ & \\
\hline
\end{tabular}

Sumber: Hasil Rekapitulasi dari Kuesioner, diolah penulis 2013

Tabel 9. Posisi Manajer MenengahBerdasarkan Klasifikasi Bentuk Badan Usaha BUMN

\begin{tabular}{|c|c|c|c|c|c|c|c|c|}
\hline \multirow{2}{*}{ MANAJER } & \multicolumn{6}{|c|}{ BENTUK BADAN USAHA BUMN } & \multirow{2}{*}{ JML } & \multirow{2}{*}{$(\%)$} \\
\hline & PERUM & $\%$ & PERSERO & $\%$ & $\begin{array}{l}\text { PERSERO } \\
\text { TERBUKA }\end{array}$ & $\%$ & & \\
\hline Human Capital/SDM & 8 & 25.00 & 118 & 33.05 & 11 & 27.50 & 137 & 31.93 \\
\hline Pemasaran/Marketing & 6 & 18.75 & 97 & 27.17 & 9 & 22.50 & 112 & 26.11 \\
\hline Produksi/Operasi & 7 & 21.88 & 68 & 19.05 & 7 & 17.50 & 82 & 19.11 \\
\hline Keuangan/Accounting & 7 & 21.88 & 66 & 18.49 & 9 & 22.50 & 82 & 19.11 \\
\hline Manajer Lainnya & 4 & 12.50 & 8 & 2.24 & 4 & 10.00 & 16 & 3.73 \\
\hline Jumlah & 32 & 100 & 357 & 100 & 40 & 100 & 429 & 100 \\
\hline$\%$ & 7.46 & & 83.22 & & 9.32 & & 100 & \\
\hline
\end{tabular}

Sumber: Hasil Rekapitulasi dari Kuesioner, diolah penulis 2013

Deskripsi nilai statistik, skor iedalnya. Kondisi tersebut tanggapan manajer menengah termasuk kategori tinggi, artinya terhadap kualitas kehidupan kerja kualitas kehidupan kerja pada pada BUMN di Indonesia.dapat BUMN di Indonesia menunjukkan dijelaskan sebagai berikut:

Kualitas kehidupan kerja pada BUMN di Indonesia menunjukkan angka rata-rata terbobot $69,38 \%$ dari kondisi yang baik. Dengan kata lain, kualitas kehidupan kerja pada BUMN ditunjukkan oleh tanggapan manajer menengahyang belum 
optimal. Hal tersebut dinilai cukup beralasan karena masih terdapat beberapa indikator yang termasuk kategori cukup, seperti: pada dimensi partisipasi (KKK2) terutama indikator peluang untuk berkontribusi $\left(\mathrm{X}_{4}\right)$ dan ketelibatan dalam pengambilan keputusan, dan pada dimensi lingkungan fisik, terutama pada indikator total ruang untuk bekerja dan beraktivitas.

Deskripsi nilai statistik atas tanggapan manajer menenga $h$ tentang apa yang dirasakan terhadap Keterikatan Karyawan (KK) pada BUMN di Indonesia, secara keseluruhan mencapai rata-rata $61,23 \%$ dari skor idealnya. Nilai tersebut termasuk kategori tinggi. Artinya Keterikatan Karyawan pada BUMN sudah baik. Hal tersebut ditelusuri dari 3 (tiga) variabel manifes, keterikatan kognitif, keterikatan emosional, dan keterikatan perilaku.

Dengan kata lain, keterikatan karyawan pada BUMN ditunjukkan oleh persepsi manajer menengah yang belum optimal. Hal tersebut dinilai cukup beralasan karena masih terdapat beberapa indikator yang termasuk kategori cukup, seperti: pada dimensi kognitif (KK1) terutama indikator pengetahuan dan pemahaman karyawan terhadap pemimpin mereka $\left(\mathrm{Y}_{2}\right)$ dan dimensi emosional (KK2) terutama pada indikator komitmen karyawan terhadap lingkungan kerja mereka, bahkan terdapat indikator yang dinilai rendah, seperti: sikap positif manajer menengah terhadap organisasi dan pemimpin mereka $\left(\mathrm{Y}_{7 . \mathrm{b}}\right)$ pada dimensi emosional (KK2), dan indikator ketertarikatannya dengan pekerjaan yang dihadapi $\left(\mathrm{Y}_{8}\right)$ pada dimensi perilaku (KK3).

\section{PengujianModel}

Model dalam penelitian ini, dikaji dari fenomena di lapangan, dengan menggunakan variabel yang digali dari permasalahan di lapangan. Model yang terbentuk didasarkan pada teori-teori parsial antar model, sehingga dari beberapa teori pendukung tersebut diperoleh suatu bentuk model.

Pengujian model menggunakan persamaan struktural, yaitu Structural Equation Modeling (SEM), metode penaksiran didasarkan pada distribusi data. 
Sehingga perlu dilakukan uji sebaran data, apakah data diperoleh dari populasi yang berdistribusi normal atau tidak. Hair, et., al. (2010) menjelaskan bahwa jika data diperoleh dari populasi yang berdistribusi normal, maka penaksiran model dapat dilakukan dengan metode maximum likelohood. Jika data diperoleh dari populasi yang tidak berdsitribusi normal, maka metode penaksiran dilakukan dengan metode Robust Maximum Likelihood atau Generalized Least Squares (GLS). Penaksiran model dapat dilakukan dengan metode maximum likelohood. 
Tabel 10. Tanggapan Manajer Menengahterhadap Kualitas Kehidupan Kerja (KKK)

\begin{tabular}{|c|c|c|c|c|c|}
\hline No. & DIMENSI & $\begin{array}{r}\text { ACTUAL } \\
\text { SCORE }\end{array}$ & $\begin{array}{l}\text { IDEAL } \\
\text { SCORE }\end{array}$ & $\begin{array}{r}\text { WMS } \\
(\%)\end{array}$ & KET \\
\hline 1. & Keterlibatan Sosial (KKK1) & 4,675 & 6,435 & 72.65 & Tinggi \\
\hline 2. & Partisipasi (KKK2) & 2,292 & 4,290 & 53.43 & Cukup \\
\hline 3. & Kompensasi (KKK3) & 3,085 & 4,290 & 71.91 & Tinggi \\
\hline 4. & Integrasi Tempat Kerja (KKK4) & 6,156 & 8,580 & 71.75 & Tinggi \\
\hline 5. & Supervisi (KKK5) & 4,627 & 6,435 & 71.90 & Tinggi \\
\hline 6. & Lingkungan Fisik (KKK6) & 5.749 & 8.580 & 67,00 & Tinggi \\
\hline 7. & Pertumbuhan dan Pengembangan (KKK7) & 3.181 & 4.290 & 74,15 & Tinggi \\
\hline Jum & & 29,765 & 42,900 & 69.38 & Tinggi \\
\hline
\end{tabular}

Sumber: Data Primer, diolah penulis, 2013

Tabel 12. Tanggapan Manajer Menengahterhadap Keterikatan Karyawan (KK)

\begin{tabular}{llrrrr}
\hline No. & VARIABEL MANIFES & $\begin{array}{r}\text { ACTUAL } \\
\text { SCORE }\end{array}$ & $\begin{array}{r}\text { IDEAL } \\
\text { SCORE }\end{array}$ & $\mathbf{( \% )}$ & \multirow{2}{*}{ KET } \\
\hline 1 & Keterikatan Kognitif $\left(\mathrm{KK}_{1}\right)$ & 4.035 & 6,435 & 62.70 & Tinggi \\
2 & Keterikatan Emosi $\left(\mathrm{KK}_{2}\right)$ & 6.365 & 10,725 & 59.35 & Tinggi \\
3 & Keterikatan Perilaku $\left(\mathrm{KK}_{3}\right)$ & 4.048 & 6,435 & 62.91 & Tinggi \\
\hline TOTAL & $\mathbf{1 5 . 6 9 3}$ & $\mathbf{2 3 . 5 9 5}$ & 61,23 & Tinggi \\
\hline
\end{tabular}

Sumber: Data Primer, diolah penulis, 2012 
Secara keseluruhan model yang

digambarkan sebagai berikut:

dihasilkan penelitian ini dapat

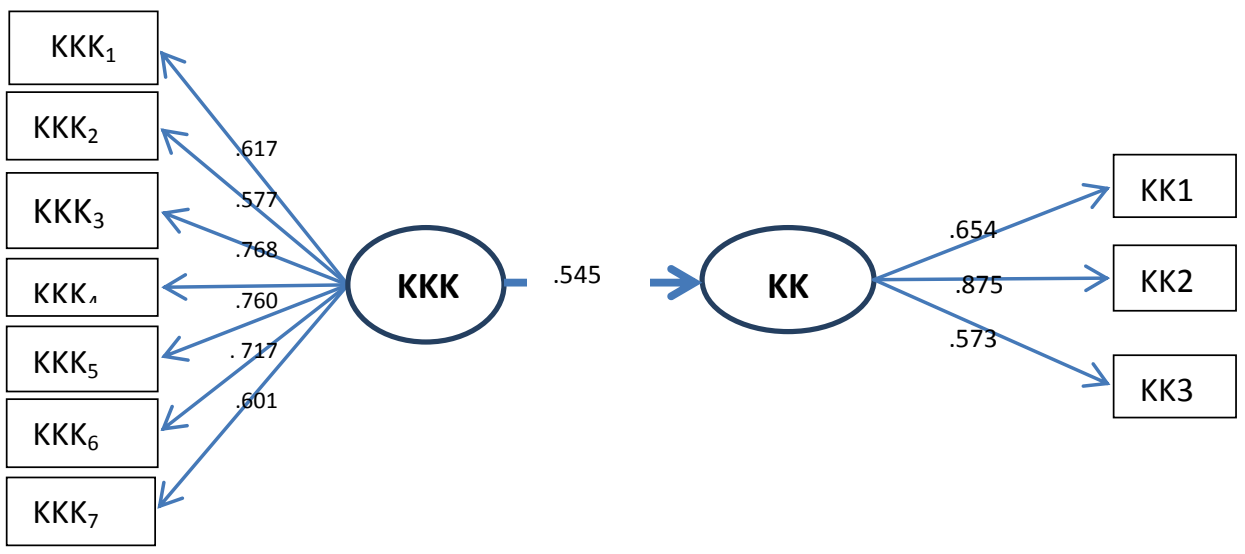

Gambar 2.

\section{Model Struktural yang Menggambarkan Pengaruh Variabel KKK dan KK}

\section{Uji Goodness of fit Statistics}

Hasil ketepatan model yang diperoleh (pengujian model secara simultan atau keseluruhan) ditunjukkan oleh ukuran kesesuaian model (Goodness of fitstatistics) dapat diringkaskan seperti terlihat pada Tabel 4.28 sebagai berikut:

Tabel 13. Evaluasi Kriteria Goodness of Fit Indices

\begin{tabular}{lccc}
\multicolumn{1}{c}{ Kriteria } & Hasil & Nilai Kritis & Evaluasi Model \\
\hline$\chi^{2}(\mathrm{CMIN})$ & 3998,169 & Diharapkan & Marginal \\
Df $=5350$ & & kecil & \\
Significance Probability & 0,0000 & $\geq 0,05$ & Marginal \\
CMIN/DF & 1,124 & $\leq 2,00$ & Baik \\
RMSEA & 0.0640 & $\leq 0,08$ & Baik \\
Goodness of Fit Index (GFI) & 0,89 & $\geq 0,90$ & Marginal \\
Normed Fit Index (NFI) & 0,97 & $\geq 0,90$ & Baik \\
\hline
\end{tabular}

Sumber : Data primer diolah, 2013 
Hasil pengujian model dengan memperhatikan nilai $\chi^{2}$, maka diperoleh nilai $\chi^{2}$ besar dengan significance probability $(0,000)$ lebih kecil dari 0,05. Tetapi karena rasio CMIN dengan DF masih kurang dari 2, maka dapat dinyatakan model struktural yang terbentuk dapat diterima (fit dengan data). Ukuran Goodness of Fit Statistics yang lainnya juga menunjukkan model masih dapat digunakan dimana RMSEA untuk model struktural 0,064 lebih kecil dari nilai kritis 0,8 dan Normed Fit Index (NFI) model 0,97 lebih besar dari nilai kritis $(0,90)$. Nilai GFI model masuk dalam kriteria marginal.

Berdasarkan ukuran kecocokan model yang diperoleh dapat disimpulkan bahwa model struktural yang terbentuk sesuai dengan data dan dapat dikatakan memenuhi kriteriGoodness of Fit.

\section{Pengujian Hipotesis dan Pembahasan Hasil Penelitian}

Pengaruh kualitas kehidupan kerja dan perilaku kewargaan organisasional terhadap keterikatan karyawan dan dampaknya terhadap kinerja perusahaan berbasis total performance score card, dalam penelitian ini dilakukan melalui analisis Structural Equation Modeling (SEM). Secara rinci diuraikan berdasarkan hipotesis yang diajukan, yaitu: (1) Kualitas kehidupan kerjadan keterikatan karyawan pada BUMN di Indonesia menunjukkan kondisi yang baik; (2) Kualitas kehidupan kerja meliputi keterlibatan sosial, partisipasi, kompensasi, integrasi target kerja, supervisi, ligkungan fisik, pertumbuhan dan pengembangan secara parisial dan simultan berpengaruh positif terhadap keterikatan karyawan pada BUMN di Indonesia

Hipotesis yang menyatakan kualitas kehidupan kerja berpengaruh terhadap keterikatan karyawan pada BUMN di Indonesia menunjukkan kondisi yang baik, dapat diterima. Artinya kualitas kehidupan kerja yang dirasakan manajer menengah sudah memadai demikian halnya keterikatan karyawan pada BUMN menunjukkan kondisi yang baik. 
Tabel 14. Pengaruh Kualitas Kehidupan Kerja terhadap Keterikatan karyawan Pada BUMN di Indonesia

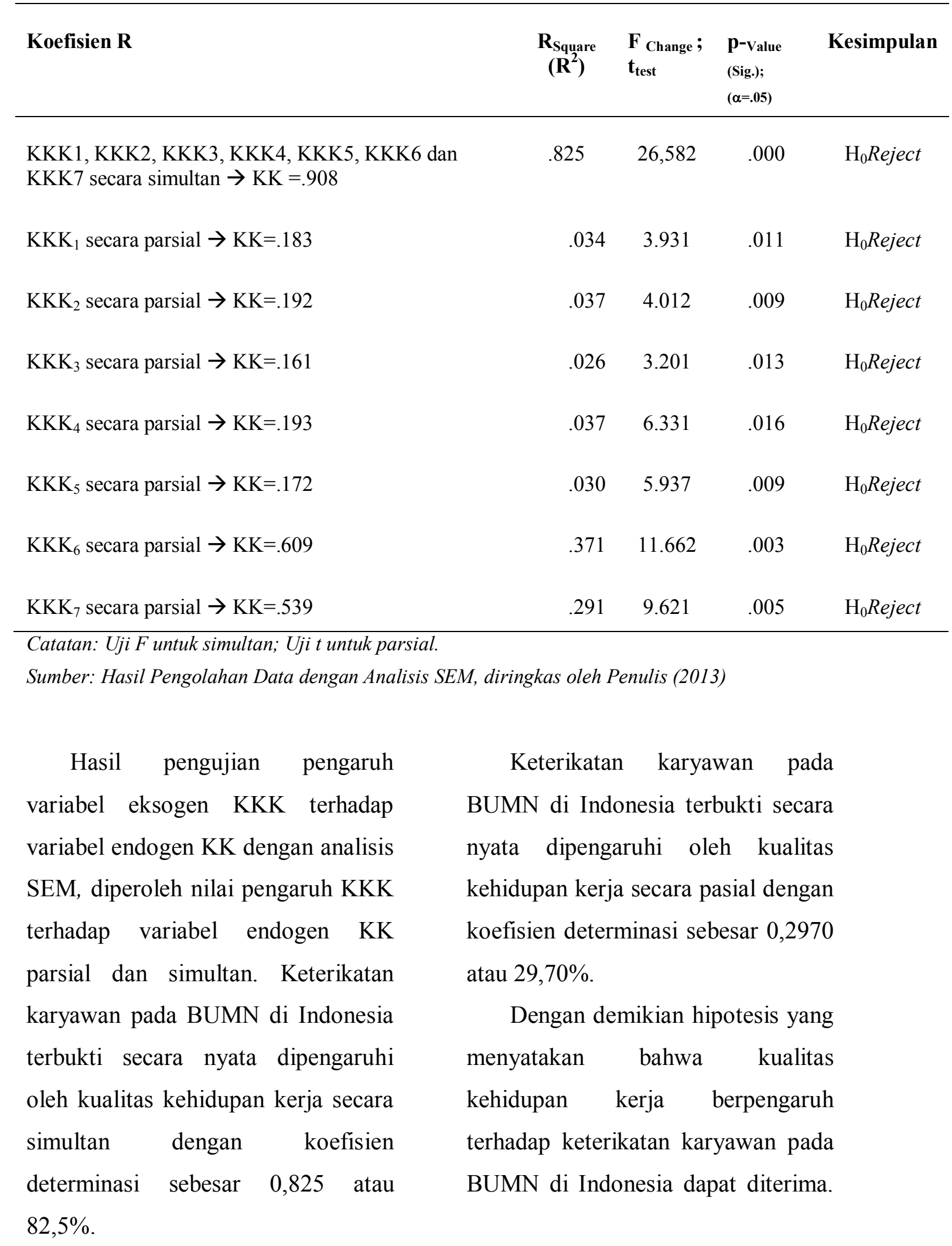


Model persamaan statistik sebagai berikut:

$$
\mathrm{KK}=0,545 \mathrm{KKK}+0,448
$$

Artinya: (1) Setiap perubahan keterikatan karyawan ke arah positif sebesar $\quad 0,545$ atau $\quad 54,5 \%$ yang digerakkan oleh manajer menengah pada BUMN turut ditentukan oleh kualitas kehidupan kerja yang dirasakan manajer menengah pada BUMN di Indonesia sebesar 1 satuan $(100 \%)$.

Dengan kata lain, kualitas kehidupan kerja yang dirasakan manajer menengah terhadap keterikatan kognitif, emosional, maupun perilaku sebagai karyawan pada BUMN di Indonesia, yaitu mencapai $29,70 \%$.

Hasil penelitian ini memperkuat hasil penelitian Haid dan Sims (2012) yang menyimpulkan bahwa kualitas kehidupan kerja akan meningkatkan:(1) komitmen karyawan terhadap pekerjaan dan organisasinya, (2) karyawan merasa bangga dalam melakukan pekerjaan dan bangga berada dalam organisasi, (3) karyawan akan bersedia untuk mendukung peningkatan manfaat dan keuntungan dari pekerjaan dan organisasi, dan (4) karyawan akan merasa puas dengan pekerjaan dan organisasi, baik emosional maupun intelektual. Keempat hal tersebut terdapat merupakan karakteristik dari keterikatan karyawan.

Hasil penelitian ini juga, memperkuat hasil penelitian Ross, et al (2006) dan Sardar, et al (2010), yang menyimpulkan bahwa karateristik yang terdapat pada keterikatan karyawan digambarkan pula oleh karakteristik yang terdapat pada kualitas kehidupan kerja.

Hasil ini juga sejalan dengan hasil penelitian Ehigie dan Otukoya (2005), yang berksimpulan bahwa perilaku kewargaan organisasional dapat meningkatkan keterikatan karyawan dengan organisasinya, terutama perusahaan milik pemerintah di Nigeria. Hasil penelitian Ehigie dan Otukoya tersebut merekomendasikan bahwa manajemen perlu menetapkan perangkat kebijakan di tempat kerja yang akan menjamin peningkatan dukungan organisasi dan perlakuan yang adil terhadap semua karyawan dari tiga aspek perilaku kewargaan organisasional, yaitu membantu, kebajikan sipil, dan sportivitas. 
Dengan kata lain, hasil penelitian ini sejalan dengan hasil penelitian sebelumnya. Meskipun demikian hasil penelitian ini menunjukkan bahwa kualitas kehidupan kerja yang dirasakan manajer menengah dan perilaku kewargaan organisasional secara parsial dan simultan berpengaruh terhadap keterikatan karyawan belum menunjukkan angka yang optimal (55,21\%). Hal tersebut mengindikasikan bahwa:

(1) Belum optimalnya kualitas kehidupan kerja karyawan yang ditunjukkan oleh masih belum optimalnya partisipasi karyawan, yang diukur dari: peluang untuk berkontribusi $\left(\mathrm{X}_{4}\right)$ hanya mencapai 50,58\%, kelibatan karyawan dalam pengambilan keputusan $\left(\mathrm{X}_{5}\right)$ hanya mencapai $56,27 \%$, dan keterbatasan total ruang untuk bekerja dan beraktivitas $\left(\mathrm{X}_{15}\right)$, yang hanya mencapai 57,76\%.

(2) Belum optimalnya perilaku kewargaan organisasional yang yang dirasakan Manajer Menengah pada BUMN selaku karyawan, ditunjukkan oleh dimensi dukungan organisasi kepadanya hanya mencapai 50,68\%. Hal tersebut terlihat dari indikator: Masih rendahnya perasaan menjadi anggota organisasi $\left(\mathrm{X}_{22}\right)$, yang hanya mencapai $34,87 \%$ dari skor idealnya, reward atau timbal balik yang dirasakan manajer menengah selaku karyawan terhadap organisasi $\left(\mathrm{X}_{28}\right)$ yang hanya mencapai $51,38 \%$ dari skor idealnya, Kontribusi yang dirasakan manajer menengah selaku karyawan terhadap organisasinya $\left(\mathrm{X}_{29}\right)$ hanya mencapai $50,68 \%$ dari skor idealnya.

(3) Belum optimalnya keterikatan karyawan yang dirasakan manajer menengah selaku manajer, yang ditunjukkan oleh indikator: pengetahuan dan pemahaman karyawan terhadap pemimpin mereka $\left(\mathrm{Y}_{2}\right)$ yang hanya mencapai $51,89 \%$ dari skor idealnya, komitmen karyawan terhadap lingkungan kerja mereka $\left(\mathrm{Y}_{6}\right)$ yang hanya mencapai $50,40 \%$ dari skor idealnya, tingginya sikap negatif $(60,37 \%)$ dan rendahnya sikap positif $(38,83 \%)$ mereka terhadap organisasi dan pemimpin mereka $\left(\mathrm{Y}_{7}\right)$, dan rendahnya $(38,04 \%)$ ketertarikan manajer atas pekerjaan yang dihadapi $\left(\mathrm{Y}_{8}\right)$. 
(4) Masih ada faktor lain (44,79\%) yang berpengaruh terhadap keterikatan karyawan pada BUMN di Indonesia, selain kualitas kehidupan kerja dan perilaku kewargaan organisasional yang diduga, di antaranya, belum adanya keseragaman (standar) kebijakan remunerasi, dalam analisis annual report (2011) BUMN ditemukan masih terdapat BUMN yang serumpun pun, tetapi tidak memiliki cara analisis jabatan dan rumusan sistem remunerasi yang sama. Pemberian remunerasi (kompenasi) baik yang bersifat finansial maupun non finansial belum ada keseragaman, sehingga memberikan peluang kepada karyawan untuk memilih perusahaan di luar yang menawarkan lebih tinggi.

Secara khusus hasil penelitian ini juga sejalan dengan teori perilaku organisasi dari Robbins dan Judge (2012) yang menyatakan keterikatan karyawan (employee engagemant) sesungguhnya tumbuh karena diciptakan dan dikembangkan oleh individu-individu yang bekerja dalam suatu organisasi, dan diterima sebagai nilai-nilai yang dipertahankan dan diturunkan kepada setiap anggota baru.

Selain itu hasil pengolahan data juga menunjukkan nilai $\mathrm{R}^{2}=0,5521$ atau $55,1 \%$. Nilai tersebut mengindikasikan bahwa masih terdapat faktor-faktor lain yang mempengaruhi keterikatan karyawan di luar kualitas kehidupan kerja dan perilaku kewargaan organisasional, yang ditunjukkan faktor residu yang mencapai 0,4479 atau $44,79 \%$. Faktor lain tersebut diduga adalah kebijakan pemerintah, politik dan/atau unsur tujuan tertentu.

\section{PENUTUP}

Berdasrkan analisis deskripsi dan pembahasan hasil penelitian ini menunjukkan bahwa:

(1) Kualitas kehidupan kerja, perilaku kewargaan orgnisasional, keterikatan karyawan pada BUMN di Indonesia menunjukkan kondisi yang baik, namun belum optimal, hal penyebabnya dapat ditelusuri:

a. Kualitas kehidupan kerja karyawan yang ditunjukkan oleh masih belum optimalnya partisipasi karyawan, 
yang diukur dari: peluang

untuk berkontribusi

hanya mencapai 50,58\%,

kelibatan karyawan dalam

pengambilan keputusan

hanya mencapai $56,27 \%$,

dan keterbatasan total

ruang untuk bekerja dan

beraktivitas, yang hanya

mencapai 57,76\%.

b. Perilaku kewargaan

organisasional yang yang

dirasakan Manajer

Menengah pada BUMN

selaku karyawan,

ditunjukkan oleh dimensi

dukungan organisasi

kepadanya hanya

mencapai 50,68\%. Hal

tersebut terlihat dari

indikator: Masih

rendahnya perasaan

menjadi anggota

organisasi, yang hanya

mencapai $34,87 \%$ dari

skor idealnya, reward

atau timbal balik yang

dirasakan manajer

menengah selaku

karyawan terhadap

organisasi, yang hanya

mencapai $51,38 \%$ dari skor idealnya. Kontribusi

yang dirasakan manajer

menengah selaku

karyawan terhadap

organisasinya, hanya

mencapai 50,68\% dari

skor idealnya.

c. Keterikatan karyawan yang dirasakan manajer menengah selaku manajer, yang ditunjukkan oleh indikator: Pengetahuan dan pemahaman karyawan terhadap pemimpin mereka, yang hanya mencapai 51,89\% dari skor idealnya, komitmen karyawan terhadap lingkungan kerja mereka, yang hanya mencapai $50,40 \%$ dari skor idealnya, tingginya sikap negatif $(60,37 \%)$ dan rendahnya sikap positif $(38,83 \%)$ mereka terhadap organisasi dan pemimpin mereka, dan rendahnya $\quad(38,04 \%)$ ketertarikan manajer atas pekerjaan yang dihadapi. 
d. Masih ada faktor lain $(44,79 \%)$ yang berpengaruh terhadap keterikatan karyawan pada BUMN di Indonesia, selain kualitas kehidupan kerja dan perilaku kewargaan organisasional yang diduga, di antaranya, belum adanya keseragaman (standar) kebijakan remunerasi, dalam analisis annual report (2011) pada seluruh BUMN di Indonesia, ditemukan masih terdapat BUMN yang serumpun, tetapi tidak memiliki cara analisis jabatan dan rumusan sistem remunerasi yang sama. Pemberian remunerasi (kompenasi) baik yang bersifat finansial maupun non finansial belum ada keseragaman, sehingga memberikan peluang kepada karyawan untuk memilih perusahaan di luar yang menawarkan lebih tinggi.
(2) Kualitas kehidupan kerja berpengaruh positif dan bermakna terhadap keterikatan karyawan pada BUMN di Indonesia. Implikasi dari penelitian ini, memerlukan kerja keras para manajer pada level 1 dan 2 di bawah direktur dan di atas manajer pelaksana, dengan memadukan kepentingan manajer selaku agent, dan kepentingan stakeholder selaku principal. Memerlukan kearifan dan kebijakan dalam pengambilan keputusan dengan menerapkan sistem partisipasi dari bawah ke atas (bottom up) dan partisipasi dari atas ke bawah (top down). 


\section{DAFTAR PUSTAKA}

Acquaah, Moses and Eddy K. Tuukamushaba, 2010. Human Factor, Organizational Justice and Preived Organizational Effectiveness: An Empirical Analysis From Ghana and Uganda. Repositioning African Business and for the $21^{\text {st }}$ Century Simon Siguē (ed.). pp 365-368.

Alien, D. T. 2006. Rewarding Good Citizen: The Relationship Between Citizenship Behavior, Gender and Organizational Reward. Journal of Applied Social Psychology. Vol. 36., No.1., pp. 120-143.

Aon Hewitt. 2012. Trends in Global Employee Engagement. Aon Hewit. http://www.aon.com/attachments/thought-

leadership/Trends_Global_Employee_Engagement_Final.pdf., [diakses 08/08/2012]

Asgari, Ali., Abu Daud Silong, Aminah Ahmad, Bahaman Abu Samah, 2008. The Relationship Between Transformational Leadership Behavior, Organizational Justice, Leader-Member Exchange, Perceived Organizational Support, Trust in Management and Organizational Citizenship Behavior. European Journal of Scientific Research. Vol.23., No.2., pp.227-242.

Ball, K. T. 2006. LMX-Citizenship Behavior Relationship: Justice as a Mediator. Leadership and Organization Development Journal. Vol. 27., No. 2., pp. 106117.

Barney, Jay B., William S. Hesterly. 2012. Strategic Management and Competitive Advantage: Concept and Cases. $4^{\text {th }}$ Edition. USA: Pearson.

Becker, Brian E, Mark A. Huselid, and Dave Urlich, 2009. The HR Scorecard: Linking People, Strategy, and Performance. USA: Harvard College.

Bernardin, H. John and Jouce E. A. Russel. 2013. Human Resource Management: An Experiential Approach. $6^{\text {th }}$ Edition. New York: McGraw-Hill.

Brace, Ian. 2008. Questionnaire Design: How to Plan, Structure and Write Survey Material for Effective Market Research. $2^{\text {nd }}$ Edition. Market Research in Practice. London: Kogan Page.

Buckingham, Marcus and Curt Coffman. 2012. A Work Engagement Survey. http://www.rds-net.com/programs/work engagement survey.html 
Çakar, N.D. and Erturk, A., 2010. Comparing Innovation Capability of Small and Medium-Sized Enterprises: Examining Effects of Organizational Culture and Empowerment. Journal of Small Business Management., pp 325-359.

Cameron, Kim S., and Robert E. Quinn.2006. Diagnosing and Changing Organizational Culture: Based On The Competing Values Framework. Revised Edition. USA: Jossey-Bass.

\section{Carbonara, Scott. 2012. Manager's Guide to Employee Engagement. McGraw-Hill.}

Carlson, D. S., Kacmar, K. M., Wayne, J. H., and Grzywacz, J. G. 2006. Measuring The Positive Side of The Work-Family Interface: Development and validation of a work-family enrichment scale. Journal of Vocational Behavior, 68, 131-164.

Carton, Robert B., and Charles W. Hofer, 2006. Measuring Organizational Performance. USA: Edward Elgar Publishing Limited.

Cascio, W.F., 2013. Managing Human Resources: Productivity, Quality Work of Life, Profits. $9^{\text {th }}$ Edition. Burr Ridge, IL: McGraw-Hill Irwin.

Cascio, W.F and J. Boudreau. 2012. Short Introduction to Human Resource Strategy. Cambridge-UK: Cambridge University Press.

Cascio, W.F and H. Aguinis. 2011. Applied Psychology in Human Resource Management. $7^{\text {th }}$ Edition. Englewood Cliffs-New Jersey: Prentice-Hall.

Casper, W. J., and C. M. Harris, 2008. Work-life Benefits and Organizational Attachment: Self-Interest Utility and Signaling Theory Models. Journal of Applied Psychology, Vol. 92, pp. 28-43.

Castle, N G, 2007. Assessing Job Satisfaction of Nurse Aides In Nursing Homes: The Nursing Home Nurse Aide Job Satisfaction Questionnaire. Journal of Geontological Nursing, Vol. 33 No.5, pp. $41-47$

Cetin, M. 2006. The Relationship Between Job Satisfaction, Occupational And Organizational Commitment of Academics. Journal of American Academy of Business. Cambridge, Vol. 8, No. I., pp. 78-88

Chalboub, Michel Soto., 2010. Innovation Management and Thought Leadership - A Cultural Requirement in a Global Competitive Environment. The Journal of American Academy of Business, Cambridge, Vol. 16., No. 1.

Chang, S., and Lee, M. 2006. Relationship Among Personality Traits, Job Characteristics, Job Satisfaction, and Organizational Commitment: An empirical study in Taiwan. The Business Review. Vol. 6., No. I, pp. 201-207. 
Chiaburu, D. S., and S.V. Marino. 2006. Employee Role Enlargement: Interactions of trust and organizational fairness. Leadership \& Organizational Development Journal. Vol. 27 No. 3, pp.168-182.

Chien, Min-Huei. 2011. A Study to Improve Organizational Citizenship Behaviors. http.www.mssanz.org.au/MODSIM03/Vaol_3/B14/03_Chein_Behaviors.pdf, 04/07/2011.

Chiu, S., and M. Tsai, 2006. Relationship Among Burnout, Job Involvement, and Organizational Citizenship Behavior. The Journal of Psychology 140 (6)-517530.

CIPD Staff, 2008. Employee Engagement. CIPD. http://www.cipd.co.uk/subjects/ empreltns/general/empengmt.htm. Retrieved 2011-10-July.

Cochran, William G. 2010. Sampling Techniques. $5^{\text {th }}$ Edition. John Wiley \& Son, Inc

Cooper, D. R., and Schindler, P. S. 2006. Business Research Methods, $7^{\text {th }}$ Edition. Singapore: McGraw-Hill.

Cronbach, Lee J. and Paul E. Meehl. 1955. Construct Validity in Psychological Test. Psychological Bulettin. Vol.53, No.4 July, pp. 281-302.

Cronbach, Lee S., 1951. Coefficient Alpha and the Internal Structure of Test. Psychometric, vol. XVI, pp.297-334.

De Janasz, Suzana C., Karen D. Dowd, and Beth Z. Seneider, 2009. Interpersonal Skill in Organizations. $3^{\text {rd }}$ Edition. New York: McGraw-Hill.

Dessler, Gary. 2011. Human Resource Management. $12^{\text {th }}$ Edition. Prentice Hall.

Diamond, Harried and Linda Eve Diamond, 2010. Perfect Phrases for Motivating and Reawarding Employees. $2^{\text {nd }}$ New York: MacGraw-Hill.

Dicke, Colin. 2011. Employee Engagement: I Want It, What is it ?.http://www.irl.cornell.edu/cahrs/research/whitepapers/uplod/EmployeeEngage mentWhatisit.pdf.04/04/2011.

Dollard, Maureen and Arnold B Bakker. 2010. Psychosocial Safety Climate as a Precursor to Conducive Work Environments, Psychological Healt Problem, and Employee Engagement. Journal Occupational and Organizational Psychology. Vol. 83., Issue.3, p.579.

Dunne, Danielle D, Shanthi Gopalakrishnan, Joanne L. Scillitoe. 2009. An Empirical Study of The Impact of Firm Resources on Alliance Governance Structures. Journal of Engineering and Technology Management. Num., 26, p. 181-195. 
Duserick, F., Huang, W., and Dai, Z. 2006. Stuctural Equation Modelling For Evaluating Employee Satisfaction. Competition Forum, 4 (2): 395-404

Eriksen, Karen. 2012. Perfect Phases for Creativity and Innovation. New York: MacGraw-Hill.

Farrell, Sara K, Lisa M Finkelstein. 2011. The Impact of Motive Attributions on Coworker Justice Perceptions of Rewarded Organizational Citizenship Behavior. Journal of Business and Psychology. New York: Mar 2011. Vol. 26, Iss. 1; pg. 57.

Farr-Wharton, R., and Brunette, Y. 2007. Organizational Relationship Quality And Service Employee Acceptance of Change in SMEs: A social exchange perspective. Journal of Management and Organization, 13:114-125.

Ferris, D., H. Lian, D. Brown, F. Pang, and L.Keeping. 2010. Self-Esteem and JobPerformance: The Moderating Role of Self-EsteemContingencies.Personnel Psychology. Vol. 63. No.3, pp. 561-593.

Feruniak, Geoffey S. 2008. The Promise of Quality of Life. Journal of Employment Counseling. June 2008. Vol. 45, pp.50-75.

Finney, Martha I., 2010. The Truth About Getting The Best From People. Engagement. Jakarta: PPM

Fisher, C.D., Schoenfeldt, L.F., dan J.B. Shaw, 2006. Advanced Human Resource Management. Boston, MA: Houghton Mifflin Customer Publishing.

Fitz-enz, Jac and Barbara Davison, 2011. How to Measure Human Resources Management. Jakarta: Kencana Prenada Media Group.

Forum Human Capital Indonesia, 2007. Excellent People: Pemikiran Strategik mengenai Human Capital Indonesia. Jakarta: Gramedia.

Gallup, 2011. Employee Engagement. http://www.gallup.com/consulting/52/ employee-engagement.aspx

Ghosh, Samir and Subrata Mukherjee, 2006. Measurement of Corporate Performance Through Balanced Scorecard: an Overview. Vidyasagar University Journal of Commerce, 113.

Gibson, James L., John M Ivancevich, and James H. Donnelly, Jr., 2006. Organizations:Behavior, Structure, Processes. $12^{\text {th }}$ Edition. New York: McGraw-Hill. 
Gong, Y., Song Cheng, and Sio-Yin Cheng, 2010. High Performance Work System and Collective OCB: a Collective Social Exchange Perspective. Human Resource Management Journal. Vol. 20, No.2. pp. 119-137.

Gonzalez, J. V., and T. G. Garazo, 2006. Structural Relationship Between Organizational Service Orientation, Contact Employee Job Satisfaction and Citizenship Behavior. International Journal of Service Industry Management, 17 (I): $23-50$

Haid, Michael and Jamie Sims. 2012. Employee Engagement Maximizing Organizational Performance. Right Management. Business and Talent Organization. $\quad$ http://www.aon.com/human-capital-consulting/thoughtleadership/_compensation/report_global_trends_employee_engagement.jsp., akses $05 / 05 / 2012$

Halrynjo, Sigtona, 2009. Men's Work-Life Conflict: Career, Care and Self Realization: Patterns of Privileges and Dilemmas. Gender, Work and Organization. Vol.16, Num.1, pp. 100-125

Hanson, G. C., Hammer, L. B., and Colton, C. L. 2006. Development and Validation of A Multidimensional Scale of Perceived Work-Family Positive Spillover. Journal of Occupational Health Psychology, 11, 249-265.

Harter, J.K., Schmidt, F.L., and T.L. Hayes, 2010. Business-Unit Level Relationship BetweenEmployee Satisfaction, Employee Engagement, and Business Outcomes: A Meta-Analysis. Journal of Applied Psychology, Vol.87, pp.26879

Hay Group. 2011. "Engage Employees and Boost Performance". Archived from the original on 2011-11-23. http://web.archive.org/web/20061123123100/ http://haygroup.ca/pdf/knowledge_engaged_performance_working_paper.pdf. Retrieved 2011-11-27.

Holmes, S. A., Langford, M., Welch, 0. J., and Welch, S. T. 2010. Association Between Internal Controls and Organizational Citizenship Behavior. Journal of Managerial Issues, 14 (I): 85-99

House, Robert, Paul J. Hanges, Mansour Javidan, Peter W. Dorfman, and Vipin Gupta, 2010. Culture, Leadership, and Organizations: The Globe Study of 62 Sociaeties. London: Sage Publication, Inc.

Hwang, I., and Kuo, J. 2006. Effects of Job Satisfaction and Perceived Alternative Employment Opportunities on Turnover Intention: An Examination of Public? 
Sector Organizations. Journal of American Academy of Business, Cambridge, 8 (2): 254-258.

Idrus, Muhammad. 2006. Implikasi Iklim Organisasi terhadap Kepuasan Kerja dan KualitasKehidupan Kerja Karyawan. Jurnal Psikologi Universitas Diponogoro. Vol. 3. No. 1, hal. 1-8

Ireland, Duane. R., Robert E. Hoskisson, and Michael A. Hitt, 2011. The Management of Strategy: Concept and Cases. $9^{\text {th }}$ Edition. Australia: South-Western.

Islam, Md. Zohurul dan Sununta Siengthai. 2009. Quality of Work Life and Organizational Performance: Empirical Evidence from Dhaka Export Processing Zone. This paper is prepared for the ILO Conference on 'Regulating for Decent Work, to be held at the International Labour Office, Geneva.

Jahangir, N., Akbar, M. M., and Begum, N. 2006. The Impact of Social Power Bases, Procedural Justice, Job Satisfaction, and Organizational Commitment on Employees' Turnover Intention. South Asian Journal of Management, 13 (4): $72-88$

James, Jacquelyn Boone, Sharon McKechnie, and Jennifer Swanberg. 2011. Predicting Employee Engagement in an Age-Diverse Retail Workforce. Journal Occupational and Organizational Psychology. Vol. 32., Issue.2, p.173.

Javidan, Mansour., 2010. Performance Orientation: in Organization Leadership: Literature Review, Theoretical Rationale, and Globe Project Goal.

Jiao, Changquan , David A Richards, and Kai Zhang., 2011. Leadership and Organizational Citizenship Behavior: OCB-Specific Meanings As Mediators. Journal of Business and Psychology. New York: Mar. Vol. 26, Iss. 1; pg. 11

Kahn, W.A. 2010. Psychological Conditions of Personal Engagement and Disengagement AtWork. Academy of Management Journal, Vol. 33, pp.692724.

Kandlousi, Nader Sheykh Al Eslami., Anees Janee Ali, and Anahita Abdollahi, 2010. Organizational Citizenship Behavior in Concern of Communication Satisfaction: The Role of the Formal and Informal Communication. International Journal of Business and Management. Canadian Center of Science and Education. Vol 5, No 10., pp. 51-61

Kessler, Robin, 2011. Competency Based Performance Reviews: Evaluasi Kinerja Karyawan untuk mencapai sasaran strategi organisasi. Jakarta: PPM 
Kisejerski, Val and Berna J. Skrypnek. 2008. Four Paths to Spirit at Work: Journeys of Personal Meaning, Fulfillment, Well-Being, and Transcendence Trough Work. The Career Development Quartely. Vol.56., pp.319-329.

Konrad, Alison M. 2006. Engaging Employees through High-Involvement Work Practices. Ivey Business Journal. http://web.ebscohost.com/ehost/pdf?vid= $\underline{54 \& \text { hid }=120 \& \text { sid=5d29fefe-0913-49de-82b6-9b95ee1a4f09\%40sessionmgr }}$ 105. Retrieved 2006-11-14.

Koys, D. J. 2007. The Effects of Employee Satisfaction, Organizational Citizenship Behavior, And Turnover on Organizational Effectiveness: A unit-level, longitudinal study. Personnel Psychology, 54 (I): 101-114

Kreitner, Robert, and Anggelo Kinicki. 2007. Organization Behavior. $7^{\text {th }}$ Edition, New York; McGraw-Hall Inc.

Krishnan, Ramesh, Roamah Omar, Ida Rosnita Ismail, Mazuri Abd Ghani, and Kasturi Kanchymalay. 2010. Job Satisfaction as a Potential Mediator Between Motivational Job Characteristics and Organizational Citizenship Behavior: Evidance from Malaysia. Journal of Information Technology and Economic Development. October. Vol. 1 No.1, pp 86-110.

Kruse, Kevin. 2012. Employee Engagement: How to Motivate Your Team for High Performance (A Real-World Guide for Busy Managers).USA: The Kruse Group.

Kwan, H. K., and Y. Mao, 2008. Role of Citizenship Behavior on Personal Learning and Work-Family Enrichment. Paper presented at the 2008 Academy of Management Conference, Los Angeles, CA.

Liang, S., H. Ling and Hsieh, S. 2007. The Mediating Effects of Leader-Member Exchange Quality to Influence The Relationships Between Paternalistic Leadership and Organizational Citizenship Behavior. Journal of American Academy of Business, 10(2): 127-137

Lockwood, Nancy R. 2007. Leveraging Employee Engagement for Competitive Advantage: HR's Strategic Role." HR Magazine Mar. 2007: 1-11. Search Spot. ABI/INFORM Global (PQ). McIntyre Library, Eau Claire. 22 Apr. $<$ http://proquest.umi.com/pqdweb?did=1231781861\&Fmt=4\&VInst=PROD\& VType $=$ PQD $\&$ RQT $=309 \&$ VName $=$ PQD $\&>$ 
Luthans, F. dan S.J. Peterson. 2007. Employee Engagement and Manager SelfEfficacy: Implication for Managerial Effectiveness and Development. Journal of Management Development, Vol. 4, No.5.

Maheshwari, V. 2008. Employee Engagement In Driving Business Performance. Proceeding dari Seminar Pembaruan Manajemen Bisnis Indonesia. Seminar Nasional Manajemen Bisnis Indonesia ke-2. Prasetiya Mulya Business School. Jakarta.

Makhijani, Naresh., Krishnan Rajendran., and James Creelman, 2009. Managing Human Capital in Indonesia: Best Practices in Aligning People With Strategic Goals. Azkia Publisher.

Marcus, Alfred A. 2012. Management Strategy: Achieving Sustained Competitive Advantage. $2^{\text {nd }}$ Edition. New York: McGrawa Hill.

Mardanov, I., J. Sterrett, and J. Baker., 2007. Satisfaction with Supervision and Member Job Satisfaction in Leader-Member Exchange: an Empirical Study in The Restaurant Industry. Journal of Applied Management and Entrepreneur ship, Vol.12 No.3, pp. 37-56

Markos, Solomon and M. Sandhlya Sridevi. 2010. Employee Engagement: The Key to Improving Performance. International Journal of Business and Management. December 2010; Vol.5, No.12.

Martinez-Tur, V., J. M. Peiro, J., Ramos, and C.Moliner, 2006. Justice Perception As Predictors of Customer Satisfaction: The Impact of Distributive, Procedural, and Interactional Justice. Journal of Applied Social Psychology. Vol. 36 No.1: 100119.

McShane, Steven L., Mary Ann Von Glinow, 2010. Organizational Behavior: Emerging Knowledge and Practice for The Real Word. $5^{\text {th }}$ Edition. New York: McGraw-Hill.

Mesmer-Magnus, J. R., and C. Viswesvaran, 2006. How family-friendly work environments affect work/family conflict: A meta-analytic examination. Journal of Labor Research. Vol.4,pp. 555-574.

Mondy, R. Wayne, and Judy Bandy Mondy. 2012. Human Resource Management. $12^{\text {th }}$ Edition. England: Prentice Hall.

Noe, Raymond A., John R. Hollenbeck, Barry Gerhant, and Patrick M. Wright. 2010. Human Resource Management. $7^{\text {th }}$ Edition. New York: McGraw-Hill. 
PearceII, John A., Richard B. Robinson, Jr. 2011. Strategic Management: Formulation, Implementation, and Control. $12^{\text {th }}$ Edition. Boston: McGraw Hill Irwin.

Pearl, Mona. 2007. Creating a Competitive Edge: The Value of Cross-Industry Knowledge. Business Strategy Series. Vol. 8., No. 4, p. 254-261.

Pemerintah RI, 2010. Undang-undang Nomor 19 Tahun 2003 tentang BUMN. Jakarat: Kementerian Hum dan Ham RI.

Plenert, Gerhard. 1999. World Class Manager (Alibahasa: Hari Suminto). Jakarta: Interaksara.

Organ, D.W., P.M., Podsakoff, and S.B. McKenzie, 2006. Organizational Citizenship Behavior: Its Nature, Antecedents, and Consequences, Thousand Oaks, CA: SAGE.

Rashid,Hafiz Abdur, Ammar Asad, and Mian Muhammad Ashraf. 2011. Factors Persuading Employee Engagement and Linkage of EE to Personal \& Organizational Performance. Interdisciplinary Journal of Contemporary Research in Business. Vol. 3 No.5, pp. 98-108.

Rethinam, Guna Seelan and Maimunah Ismail, 2008. Costruct of Quality of Work Life: A Perspective of Information and Technology Professionals. European Journal of Social Sciences. Vol. 7. No. 1, pp.58-70.

Robbins, Stephen P., and Timoty A. Judge., 2012. Organizational Behavior. $15^{\text {th }}$ Edition. New Jersey : Prentice-Hall International Inc.

Robinson, Dilys and Sue Hayday. 2011. "Employee Engagement". In Brief (129). http://www.employment-studies.co.uk/news/129theme.php. Retrieved 2011-1106.

Rose, Raduan Che, LooSee Beh, Jegak Uli and Khairuddin Idris. 2006. An Analysis of Quality Work of Life and Caree-Related Variables. American Journal of Applied Science. Vol.3., No.12, pp.2151-2159.

Saks, A. M. 2006. Antecedents and Consequences of Employee Engagement. Journal Managerial Psychology, Vol. 21, No.7

Saraji, G. Nasl and H Dargahi. 2006. Study of Quality of Work Life. Iranian Journal Public Health. Vol.35., No. 4., pp.8-14.

Sardar, Saima., Adul Rechman, Usman Yousuaf, and Asad Yousaf. 2011. Impact of HR Practices on Employee Engagement in Banking Sector of Pakistan. Interdisciplinary Journal of Contemporary Research in Business. January, Vol.2 No.2, pp.378-389. 
Scherrer, Pascal., Lynnaire Sheridan, Ruth Sibson, Maria M. Ryan, and Nadine Henly. 2010. Employee Engagement with A Corporate Physical Activity Program: The Global Corporate Challenge. International Journal of Business Studies. June 2011. Vol. 18.No.1.,pp.125-139.

Sparr, Jennifer L., and Sabine Sonnentag. 2008. Feedback Environment and Well-Being at Work: The Mediating Role of Personal Control and Feelings of Helplessness. European Journal of Work and Organizational Psychology. Vol. 17. No.3., pp.388-412.

Sun, L.Y., Aryee, S. and Law, K.S. 2007. High-Performance Human Resource Practices, Citizenship Behaviors and Organizational Performance: ARelational Perspective. Academy of Management Journal. Vol. 50. No. 3, pp. 558-577.

Torlak, 0., and U. Koc, 2007. Materialistic Attitude as an Antecedent of Organizational Citizenship Behavior. Management Research News. Vol. 30 No. 8, pp. 581-596

Urlich, Dave. 2008. Human Resource Champions: The Next Agenda for Adding Value and Delivering Results.

Vazirani, Nitin., 2011. Employee Engagement. Working Paper. Vol. 05. No.07. SIES College of Management Studies Neru.

Visidata Riset Indonesia, 2009. Anatomi dan Konglomerasi BUMN di Indonesia. Jakarta: VRI Market Research \& Feasibility Studies.

Visidata Riset Indonesia, 2010. Privatisasi BUMN. Jakarta: VRI Market Research and Feasibility Studies.

Walton, R.E., Criteria for Quality of Working Life. Dalam Rose, Raduan Che, LooSee Beh, Jegak Uli and Khairuddin Idris. 2006. An Analysis of Quality Work of Life and Caree-Related Variables. American Journal of Applied Science. Vol.3., No.12, pp.2151-2159.

Watson Wyatt Worldwide. 2011. Employee Commitment Remains Unchanged.http://www.watsonwyatt.com/research/resrender.asp?id=W-

557\&page $=6$. Retrieved 2011-11-07.

Wellins, Richard S., Paul Bernthal, Mark Phelps. 2012. Employee Engagement: The Key to Realizing Competitive Advantage. Competitive Advantage Realized Journal. Development Dimensions International. Inc.

Wilson, Kevin. 2009. A Survey of Employee Engagement. A Dissertation. Faculty of the Raduate School. University of Missouri-Columbia. 